\title{
Penyuluhan Manajemen Pencatatan Usahatani Sebagai Upaya Peningkatan Kompetensi Petani di Desa Otak Rarangan Kabupaten Lombok Timur
}

\author{
Dudi Septiadi $^{1^{*}}$, Rosmilawati ${ }^{1}$, Abdullah Usman ${ }^{1}$, I Gusti Lanang Parta Tanaya ${ }^{1}$, Asri Hidayati ${ }^{1}$ \\ ${ }^{1}$ (Program Studi Agribisnis, Fakultas Pertanian Universitas Mataram, Mataram - Indonesia.
}

Article history

Received: 6 Desember 2021

Revised: 8 Desember 2021

Accepted: 17 Desember 2021

*Corresponding Author:

Dudi Septiadi,

Program Studi Agribisnis, Fakultas Pertanian Universitas Mataram, Mataram - Indonesia Email: dudi@unram.ac.id
Abstract: Farm bookkeeping is an essential activity in farm management. Farm registration is an effective medium in controlling farm financial management policies. The purpose of this service activity is to; 1) provide understanding to farmers regarding the management of farm books; 2) provide skills to farmers to make farming bookkeeping. Community service activities were carried out in Otak Rarangan Village, East Lombok Regency. This activity was carried out with the target of farmers from representatives of farmer group organizations. The method of implementing the activities is the Forum Group Discussion (FGD) and Workshop methods. The method of measuring the level of understanding and skills related to management of farm bookkeeping uses a pre-test and post-test questionnaire instrument during extension activities. Based on the results of the pre-test and post-test at the time of service activities, there has been an increase in understanding of farm bookkeeping management, the understanding category increased from $25 \%$ to $45 \%$, the category of understanding enough increased from $40 \%$ to $55 \%$ and the category of not understanding decreased from $35 \%$ to $0 \%$. The results of the pre-test and post-test also showed that there was an increase in the skills of farmers in making farming bookkeeping records, where the skilled category increased from $20 \%$ to $40 \%$, the category of fairly understanding increased from $30 \%$ to $50 \%$ and the category of not understanding decreased from $50 \%$ to $10 \%$.

Keywords: bookkeeping; competency improvement; community service

Abstrak: Pencatatan dalam pembukuan usahatani merupakanan kegiatan esensial dalam manajemen usahatani. Pencatatan usahatani merupakan media yang efektif dalam mengontrol kebijakan pengelolaan keuangan usahatani. Tujuan kegiatan pengabdian ini adalah untuk; 1) memberikan pemahaman kepada petani terkait manajemen pencatatan usahatani; 2) memberikan keterampilan kepada petani untuk membuat catatan pembukuan usahatani. Pengabdian dilaksanakan di Desa Otak Rarangan, Kabupaten Lombok Timur. Sasaran kegiatan adalah para petani dari perwakilan kelompok tani. Metode pelaksanaan kegiatan dengan metode Forum Group Discussion (FGD) dan Workshop. Metode pengukuran tingkat pemahaman dan keterampilan terkait manajemen pencatatan usahatani menggunakan instrumen kuesioner pre-test dan post-test pada saat kegiatan penyuluhan. Berdasarkan Hasil pre-test dan post-test pada saat kegiatan pengabdian, telah terjadi peningkatan pemahaman manajemen pencatatan usahatani, kategori paham meningkat dari $25 \%$ menjadi $45 \%$, kategori cukup paham meningkat dari $40 \%$ menjadi $55 \%$ dan kategori tidak paham menurun dari $35 \%$ menjadi $0 \%$. Hasil pre-test dan post-test juga menunjukkan terjadi peningkatan keterampilan petani dalam membuat catatan pembukuan usahatani, dimana kategori terampil meningkat dari $20 \%$ menjadi $40 \%$, kategori cukup paham meningkat dari 30\% menjadi 50\% dan kategori tidak paham menurun dari $50 \%$ menjadi $10 \%$.

Kata kunci: peningkatan kompetensi; penyuluhan; pembukuan 


\section{PENDAHULUAN}

Petani dalam melakukan usahataninya, disamping berperan sebagai pemilik dan tenaga kerja utama, juga sebagai pengelola (manajer). Karenanya Menurut Ratnasari (2017) aspek manajemen adalah kunci kesuksesan usahatani. Sebagai pengelola, petani harus memiliki kompetensi agar bisa mengelola sumberdaya yang dimiliki, seperti lahan, modal dan tenaga kerja. Menurut Nashihuddin dan Aulianto (2015) Kompetensi merupakan kemampuan untuk melaksanakan tugas-tugas secara efektif dan merupakan refleksi dari kinerja yang dilakukan seseorang dalam menyelesaikan tugas dan pekerjaannya. Tingkat kompetensi petani memiliki peranan penting dalam mempengaruhi kemampuan petani dalam mengelola usahatani. Petani yang memiliki kompetensi yang baik tentu memiliki peluang lebih baik dalam meningkatkan tingkat kesejahteraannya.

Menurut Mubyarto (1989) usahatani yang dijalankan petani bukan sekedar berkepentingan dalam menghasilkan output produk pertanian (hasil panen) yang banyak, tapi juga berharap akan adanya peningkatan tingkat pendapatan (keuntungan) yang pada akhirnya juga meningkatkan kesejahteraan bagi petani. Artinya tujuan utama dari kegiatan usahatani yang dilakukan sebagian besar petani adalah untuk menghasilkan keuntungan agar meningkatkan kesejahteraan. Pandangan ini sejalan dengan pendapat Bagio dan Athailah (2020) yang mengungkapkan bahwa tujuan dalam usahatani yaitu bagaimana petani dapat memperbesar hasil dalam hal ini memperoleh keuntungan, sehingga kehidupan seluruh keluarganya menjadi lebih baik. Untuk mencapai tujuan tersebut petani selalu memperhitungkan untung ruginya walaupun tidak secara tertulis. Menurut Leatemia dan Sari (2012) pendapatan yang didapatkan petani selama musim tanam mungkin tampak seperti mendapat untung, akan tetapi ketika pencatatan keuangan dilakukan secara lebih rinci, seringkali petani tersebut mengalami kerugian. Hal ini terjadi karena tidak semua biaya diperhitungkan. Misalnya, tenaga kerja dalam keluarga yang membantu bertani tanpa dibayar, tetapi perlu memperhitungkan jumlah energi yang mereka keluarkan.

Salah satu kompetensi yang penting untuk dimiliki petani adalah kemampuan dalam melakukan pencatatan usahatani. Menurut Septiadi et al. (2021) manajemen pencatatan usahatani merupakan salah satu bentuk teknologi dalam usahatani dalam memonitoring kondisi keuangan usahatani. Penerapan manajemen pencatatan usahatani dapat memberikan informasi apakah usahatani yang dilakukan petani mengalami keuntungan, titik impas atau kerugian. Sehingga menurut Putri (2020) kompetensi manajemen pencatatan usahatani penting untuk dimiliki petani dalam mengelola dan mengembangkan kegiatan usahatani.

Manajemen pencatatan usahatani merupakan dokumentasi administratif dari suatu usaha bisnis di sektor pertanian, dimana dasar aplikasinya menggunakan sistem akuntansi. Tujuan utama pencatatan dalam sektor pertanian adalah untuk mengetahui penggunaan alat produksi, tenaga kerja, dan tingkat pengeluaran dan pendapatan pertanian. Menurut Tohir (1983) semua jenis bisnis membutuhkan sebuah catatan usaha dalam menjalankan usahanya, termasuk diantaranya adalah bisnis di sektor pertanian.

Pencatatan dalam bisnis usahatani memiliki beberapa keuntungan penting, diantaranya adalah; 1) Untuk mengetahui besarnya keuntungan atau kerugian dalam usahatani. 2) Mengetahui jenis transaksi yang dilakukan petani. 3) Mengevaluasi kemajuan usahatani. Akuntansi usahatani sering dipandang sebagai alat manajemen untuk kebijakan manajemen pertanian. Dengan alat ini, petani dapat menemukan kelemahan dalam menerapkan dan membuat rencana pengelolaan sebagai pengelola kebun. Pencatatan ini memungkinkan petani untuk dengan cepat memperbaiki situasi dan mencapai tujuan bisnis yang diharapkan. Hal ini didukung oleh penelitian Mariyono dan Rachmansyah (2010), dimana dalam studi tersebut menunjukkan bahwa penyuluhan pencatatan usahatani dapat meningkatkan tingkat produksi dan mengurangi biaya produksi. Oleh karena itu, sangat penting untuk mengajari dan membimbing para petani cara mengimplementasikan pencatatan usahatani.

Desa Otak Rarangan merupakan salah satu Desa di Kecamatan Wanasaba Kabupaten Lombok Timur, Penduduk di Desa Otak Rarangan sebagian besar bekerja di sektor pertanian sebagai petani. Faktor manajemen administratif usahatani merupakan salah satu faktor yang kurang mendapat perhatian dari para petani di Desa Otak Rarangan. Salah satunya adalah pencatatan usaha pertanian. Berdasarkan hasil temuan pra-penelitian yang dilakukan penulis, petani di Desa Otak Rarangan belum menerapkan pencatatan dalam kegiatan usahataninya. Petani tidak dapat memahami pentingnya pembukuan dan analisis usahatani. Keadaan ini disebabkan oleh rendahnya tingkat perilaku, sikap, pengetahuan dan keterampilan petani terkait akuntansi dan analisis usahatani. Ketertarikan untuk menjalankan penyuluhan manajemen pencatatan usahatani semakin kuat karena pemerintah 
juga membutuhkan data pertanian sebagai masukan untuk menetapkan kebijakan di sektor pertanian. Karena beberapa keterbatasan kemampuan petani di desa Otak Rarangan, terutama keterbatasan dalam penggunaan komputer, maka penerapan sistem akuntansi usahatani yang berbasis komputer tidak memungkinkan dilakukan petani, sehingga petani perlu dilatih melakukan keterampilan mencatat dan menganalisis usaha secara manual dengan metode yang sederhana, sesuai kemampuan petani. Materi penyuluhan bagi kelompok tani dari penyuluh belum membahas akuntansi dan analisis pertanian, sehingga perlu adanya pengabdian kepada masyarakat berupa penyuluhan manajemen pencatata usahatani sebagai upaya peningkatan kompetensi petani di Desa Otak Rarangan Kecamatan Wanasaba Kabupaten Lombok Timur.

\section{METODE}

\section{Metode Pelaksanaan Kegiatan Pengabdian}

Metode pelaksanaan kegiatan pengabdian pada masyarakat dilakukan dengan metode Forum Group Discussion (FGD) yang dipadukan dengan workshop manajemen pencatatan usahatani. Kegiatan FGD dilakukan dengan memberikan materi tentang peran strategis sektor pertanian dan urgensi pencatatan usaha di bidang pertanian, dilanjutkan dengan diskusi. Setelah kegiatan FGD berlangsung, kegiatan berikutnya adalah workshop pencatatan usahatani, dimana pelaksanaannya dipimpin oleh tim pelaksana pengabdian kepada masyarakat dan dibantu oleh mahasiswa dan aparat desa setempat.

\section{Sasaran Kegiatan Pengabdian}

Kegiatan pengabdian dilakukan dengan melibatkan masyarakat (mitra) yang diwakili oleh perwakilan kelompok tani sebagai sasaran kegiatan pengabdian. 20 petani dipilih sebagai peserta pengabdian yang berasal dari kelompok tani di Desa Otak Rarangan, Kecamatan Wanasaba, Kabupaten Lombok Timur. Keputusan pemilihan peserta pengabdian dikoordinasikan terlebih dahulu dengan pemerintah desa.

\section{Target Kegiatan Pengabdian}

Target kegiatan Pengabdian Pada Masyarakat ini adalah;

a. Petani mampu memahami manajemen pencatatan usahatani;

b. Petani memiliki keterampilan membuat catatan pembukuan usahatani dan berkenan untuk mengimplementasikan pencatatan usahatani secara berkelanjutan.

\section{Evaluasi Kegiatan Pengabdian}

Dalam melakukan evaluasi tingkat keberhasilan kegiatan pengabdian dilakukan dua tahap penilaian yaitu:

a. Penilaian tahap 1 merupakan penilaian pre-test kegiatan penyuluhan. Penilaian ini dilakukan untuk mengetahui kemampuan peserta penyuluhan sebelum dilaksanakan kegiatan penyuluhan dan pelatihan manajemen pencatatan usahatani.

b. Penilaian tahap 2 merupakan penilaian post-test kegiatan penyuluhan. Penilaian ini dilakukan untuk mengetahui kemampuan peserta penyuluhan setelah/pasca dilaksanakan kegiatan Penyuluhan dan pelatihan manajemen pencatatan usahatani.

\section{HASIL DAN PEMBAHASAN}

\section{Kegiatan Penyuluhan Pencatatan Usahatani sesi Forum Group Discussion (FGD)}

Kegiatan pada sesi pertama dilakukan kegiatan penyuluhan pencatatan usahatani sesi Forum Group Discussion (FGD). Kegiatan ini dilakukan dengan tujuan agar petani memiliki pemahaman dan pentingnya melakukan manajemen pencatatan usahatani. Kegiatan penyuluhan berlokasi di kantor Desa Otak Rarangan. Persiapan di tempat Pengabdian didukung oleh mahasiswa Jurusan Sosial Ekonomi Pertanian Universitas Mataram yang tinggal di dekat lokasi Pengabdian. Terdapat 20 orang dari Kelompok Tani berpartisipasi dalam acara Pengabdian ini. Para petani yang terlibat sebagian besar adalah petani yang aktif budidaya padi dan hortikultura. Petani peserta pengabdian juga menggabungkan kegiatan bertani mereka dengan aktifitas usahatani ternak seperti 
sapi dan unggas. Acara Pengabdian juga dihadiri oleh Babinsa yang berpatroli untuk memastikan acara tersebut dilaksanakan sesuai dengan protokol kesehatan yang ketat. Kepala Desa yang berhalangan hadir, diwakili oleh kadus setempat.

Kegiatan dimulai dengan sesi sambutan, dimana sambutan secara berurutan dari ketua tim pengabdian masyarakat, ketua program studi agribisnis, dan pihak pemerintah desa setempat sekaligus membuka acara kegiatan pengabdian secara resmi. Setelah pembukaan, kegiatan dilanjutkan dengan menyebarkan instrumen kuesioner pre-test kepada peserta pengabdian yang ditujukkan untuk mengukur pemahaman dan keterampilan petani terkait manajemen pencatatan usahatani. Kegiatan dilanjutkan dengan penyampaian materi untuk memotivasi petani dan memberikan pemahaman tentang manfaat dan cara-cara melakukan pencatatan dan analisis usahatani secara manual. Kegiatan tersebut ditunjukkan pada gambar 1. Selanjutnya dilakukan kegiatan diskusi terkait materi yang sudah disampaikan. Terdapat beberapa temuan penting ketika diskusi dengan petani, dimana nyaris semua petani tidak pernah melakukan pencatatan pembukuan usahatani yang mereka tekuni selama bertahun-tahun. Kegiatan pengabdian ini diharapkan sebagai pemicu bagi petani untuk mau mencatat kegiatan usahataninya dengan baik.
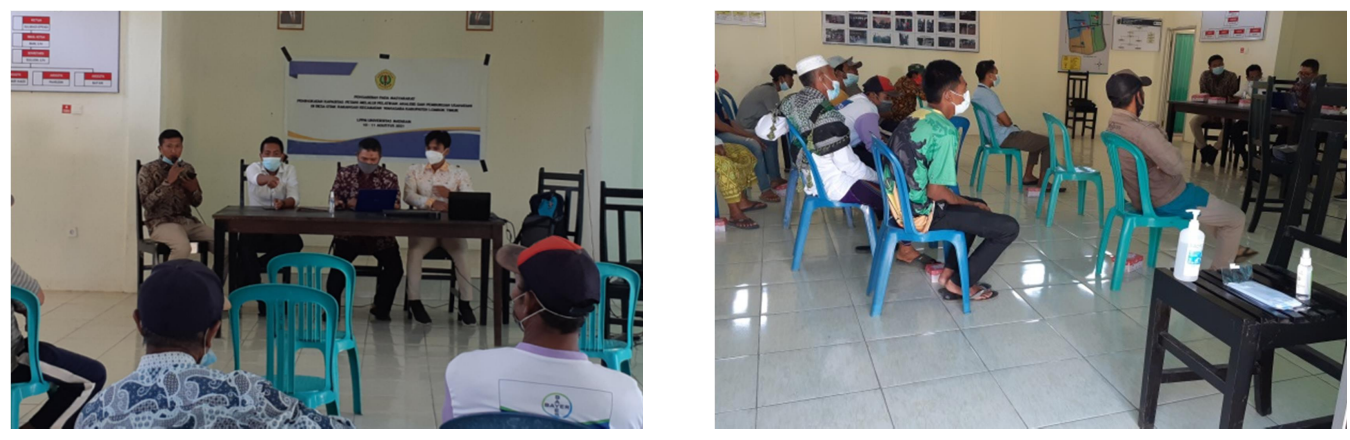

Gambar 1.

Penyampaian materi penyuluhan dilakukan dengan standar protokol kesehatan

Tujuan utama dari manajemen pencatatan usahatani adalah agar petani dapat mengetahui hasil yang sebenarnya dari operasi usahataninya. Pada buku catatan usahatani akan dapat dibaca segala sesuatu yg telah dikerjakannya pada usahatani selama satu musim tanam, sehingga petani dapat menyusun perencanaan usahatani di masa yg akan datang. Dari sisi kegunaannya, manajamen pencatatan usahatani dapat dijadikan sebagai petunjuk tentang tingkat perkembangan usahatani, seperti informasi perkembangan harga, kebutuhan sarana produksi, informmasi pendapatan, kebutuhan modal dan lain-lain.

Bagi pemerintah, peneliti \& penyuluh pertanian informasi-informasi yang tertulis tersebut merupakan sumber informasi yang berharga. Informasi berharga tersebut bisa sebagai bahan kajian para peneliti, penyuluh dan sebagai dasar pengambilan keputusan pemerintah. Selain itu catatan usahatani juga mampu untuk menilai keberhasilan usaha yaitu sebagai bukti layak tidaknya usahatani yang dijalankan atau penilaian efisiensi atau tidaknya usahatani yang dilakukan oleh petani.

Bagi petani buku catatan usahatani juga dapat dijadikan untuk referensi/pertimbangan pihak bank, ketika petani hendak melakukan pinjaman modal ke bank. Buku catatan usahatani juga memudahkan petani dalam mengamankan dan mengawasi aset yang dimiliki, sehingga mampu mencegah penyimpangan dan pemborosan. Dengan demikian catatan usahatani diharapkan bisa mengidentifikasi kekuatan dan kelemahan yang pada akhirnya sebagai tindak lanjut dalam tercapainya tujuan petani yaitu meningkatkan pendapatan dan kesejahteraan petani.

Selain mengungkapkan kelemahan dalam melakukan catatan usahatani pada pertemuan FGD. Petani juga mengeluhkan beberapa hambatan dalam kegiatan usahatani. Petani mengalami kesulitan dalam mendapatkan pupuk bersubsidi. Petani mengatakan bahwa di Desa Otak Rarangan sering kali kekurangan pasokan pupuk bersubsidi. Jika pupuk bersubsidi tersedia, seringkali jumlahnya terbatas dan harus memenuhi persyaratan administrasi yang berbelit-belit seperti harus ada kartu tani atau Kartu Keluarga, dan Kartu Tanda Penduduk. Solusi yang ditawarkan tim pelaksana pengabdian untuk mengatasi hal tersebut adalah dengan memanfaatkan potensi yang ada di lingkungan petani itu sendiri. Di desa Otak Rarangan, selain petani menjalankan usahatani seperti padi-padian dan hortikultura, petani juga menjalankan usahatani peternakan. Jenis ternak yang dibudidayakan petani di Desa Otak Rarangan sehagian hesar adalah neternakan sani. Kemungkinan menurut Nugraha (2013) kotoran vang ditimbulkan 
dari peternakan sapi bisa dimanfaatkan dengan mengolah kotoran yang tersedia menjadi pupuk kompos atau pupuk organik. Artinya menurut Huda dan Wikanta (2016) limbah kotoran sapi yang mencemari lingkungan dapat dimanfaatkan untuk mengatasi kelangkaan pupuk yang selama ini dikeluhkan petani. Hasil ini penting sebagai alasan untuk kegiatan pelayanan selanjutnya.

Selain itu, petani juga menekankan masalah harga jual hasil panen mereka yang turun drastis saat panen raya. Tim pelaksana pengabdian memberi rekomendasi lanjutan agar petani berkoordinasi dengan kelompok tani dan BUMDes untuk membangun sistem kelembagaan petani yang menyerap hasil panen petani. Lembaga ini dapat berbentuk koperasi pertanian. Menurut Nuryanti dan Swastika (2011) Koperasi pertanian terdiri dari seluruh kelompok tani yang ada. Koperasi pertanian kemudian menurut Pujiyono dan Nugraha (2016) diwajibkan untuk menyerap hasil panen petani dengan harga yang wajar dan pantas. Ini berarti keamanan harga bagi petani terjamin. Hasil panen yang diserap oleh koperasi dijual langsung ke konsumen akhir. Kehadiran Koperasi ini memperpendek rantai pasok dan menggantikan peran perantara, pengumpul dan pedagang grosir.

\section{Kegiatan Penyuluhan Manajemen Pencatatan Usahatani Sesi Workshop}

Selanjutnya, pada sesi kedua dilakukan workshop manajemen pencatatan usahatani. Kegiatan Workshop ditunjukkan pada gambar 2. Kegiatan ini dilakukan dengan tujuan agar petani memiliki keterampilan dalam manajemen pencatatan usahatani. Workshop dilakukan dengan mempraktekan (simulasi) cara melakukan pencatatan usahatani dan analisis usahatani secara sederhana. Simulasi dilakukan dengan cara masing-masing peserta mempraktekkan langsung pembukuan usahatani. Jumlah peserta adalah 20 orang yang terdiri dari perwakilan kelompok tani yang ada di desa Otak Rarangan. Para peserta terlihat aktif dalam penyuluhan sesi workshop ini, kegiatan workshop didampingi tim pelaksana pengabdian selama proses pencatatan pada buku catatan yang sudah disiapkan sebelumnya.

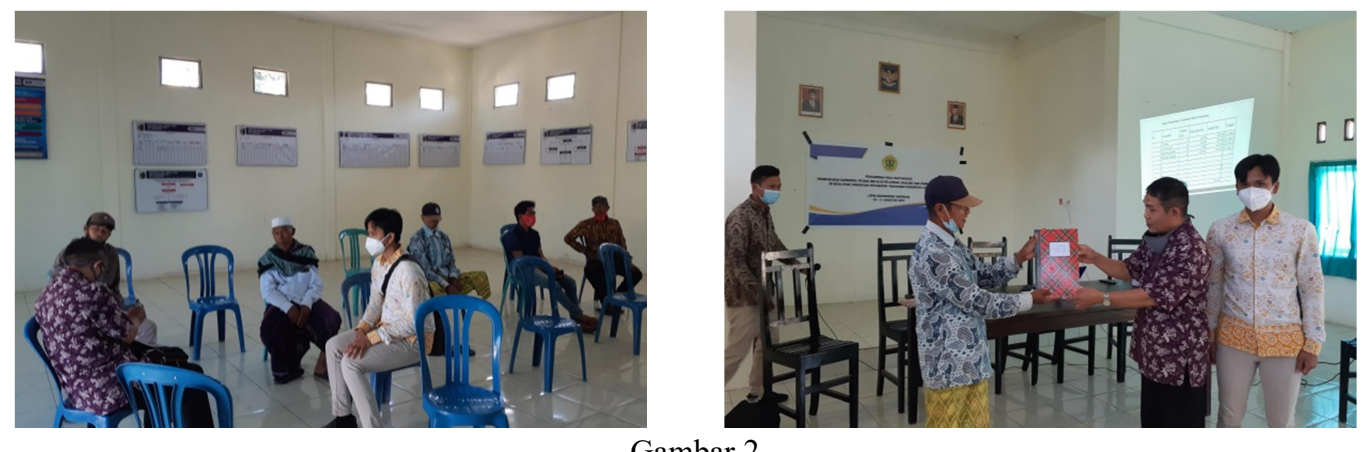

Workshop dengan peserta dan Penyerahan simbolis buku usahatani

Di akhir kegiatan, setiap peserta sudah memiliki buku catatan usahataninya masing-masing, yang sudah terisi dengan data usahatani mereka masing-masing berdasarkan pelaksanaan usahatani musim tanam yang lalu. Dan buku tersebut akan menjadi pendorong mereka untuk tetap melakukan pencatatan usahatani mereka di musimmusim tanam selanjutnya. Dalam pelatihan ini, melibatkan 1 orang mahasiswa semester akhir yang berperan dalam mendampingi dan membimbing petani dalam melakukan pencatatannya.

\section{Evaluasi Pemahaman dan Keterampilan Petani dalam pencatatan usahatani}

Evaluasi merupakan salah satu tahap dalam kegiatan pengabdian untuk mengukur ketercapaian kegiatan pengabdian pada masyarakat. Berdasarkan Gambar 3. Dapat diketahui terkait hasil pre-test dan post-test tingkat pemahaman petani di Desa Otak Rarangan terkait manajemen pencatatan usahatani. Berdasarkan Hasil pre-test dan post-test pada saat kegiatan pengabdian, telah terjadi peningkatan pengetahuan tentang manajemen pencatatan usahatani, kategori paham meningkat dari $25 \%$ menjadi $45 \%$, kategori cukup paham meningkat dari $40 \%$ menjadi $55 \%$ dan kategori tidak paham menurun dari $35 \%$ menjadi $0 \%$. 


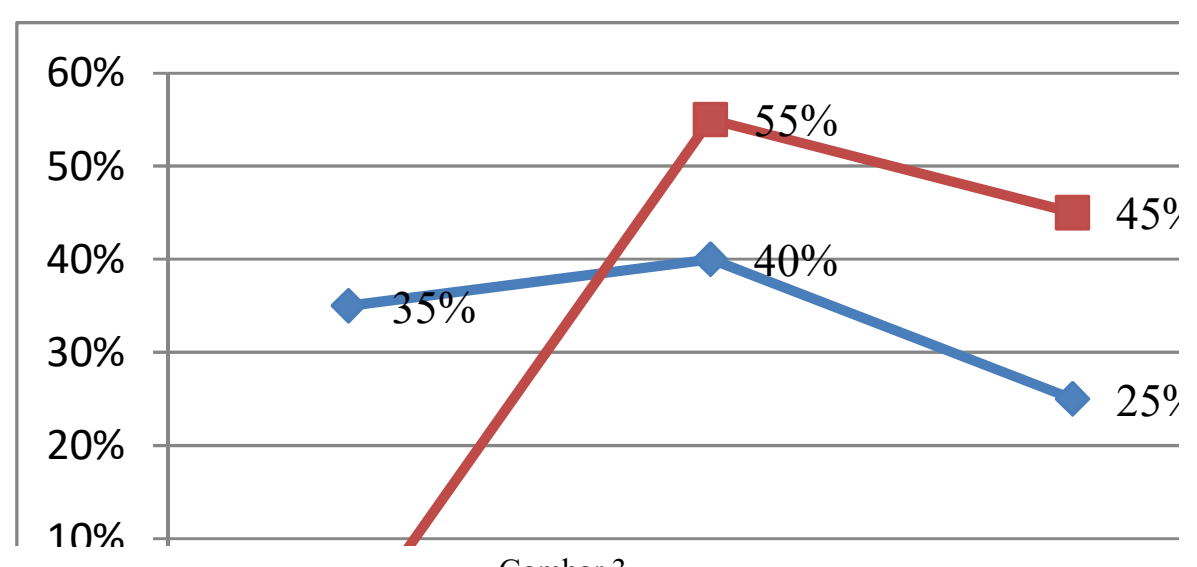

Gambar 3.

Hasil pre-test dan post-test tingkat pemahaman petani terkait manajemen pencatatan usahatani

Peningkatan kemampuan pemahaman peserta penyuluhan dikarenakan penyajian materi secara klasikal disampaikan dengan baik oleh tim penyuluhan, kemudian adanya sesi FGD menjadikan materi penyuluhan bisa dicerna dengan baik oleh peserta, karena semua kesulitan yang selama ini dialami petani disampaikan dalam sesi FGD tersebut, sehingga transfer pemahaman berjalan dengan baik.

Berdasarkan Gambar 4, dapat diketahui terkait hasil pre-test dan post-test tingkat keterampilan petani di Desa Otak Rarangan terkait manajemen pencatatan usahatani. Hasil pre-test dan post-test juga menunjukkan terjadi peningkatan keterampilan petani dalam membuat catatan pembukuan usahatani.

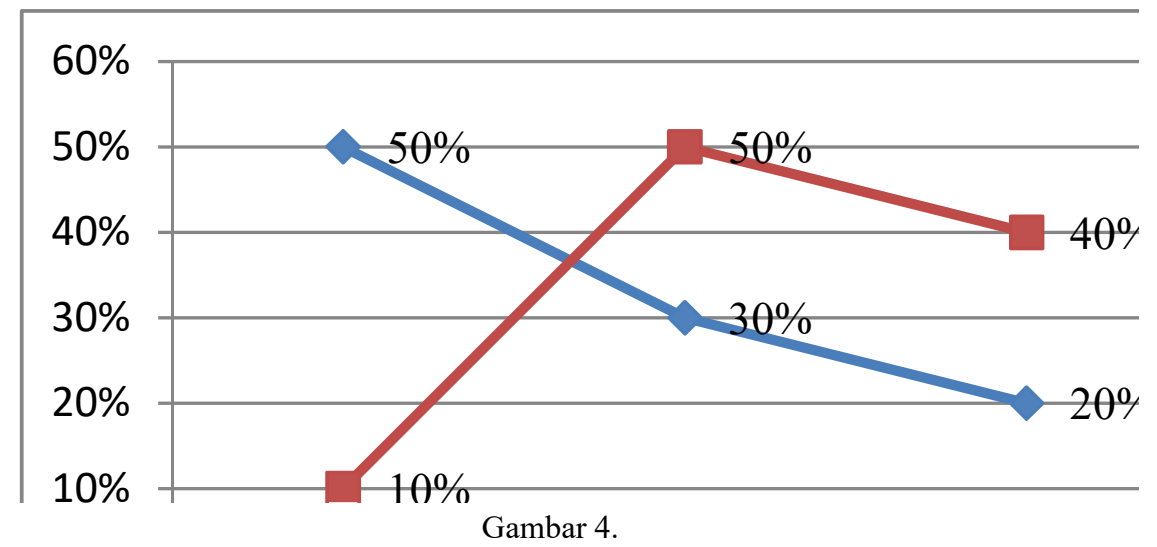

Hasil pre-test dan post-test tingkat keterampilan petani terkait manajemen pencatatan usahatani

Berdasarkan Gambar 4, kategori terampil meningkat dari 20\% menjadi 40\%, kategori cukup terampil meningkat dari $30 \%$ menjadi $50 \%$ dan kategori tidak terampil menurun dari 50\% menjadi $10 \%$. Adanya peningkatan keterampilan pencatatan usahatani dikarenkan penyampaian materi keterampilan ini disampaikan dengan metode workshop, dimana peserta dituntun oleh tim pelaksana pengabdian secara runut langkah-langkah dalam pencatatan pembukuan usahatani, sehingga peningkatan keterampilan petani dalam menyusun pencatatan pembukuan usahatani terjadi secara nyata.

Berdasarkan hasil evaluasi tersebut, tujuan kegiatan pengabdian bisa tercapai sesuai dengan target, dimana terjadi peningkatan pemahaman dan keterampilan dalam pencatatan pembukuan usahatani. Setelah kegiatan pengabdian ini, diharapkan agar petani terus melakukan kegiatan pencatatan pembukuan usahatani secara berkelanjutan di musim tanam selanjutnya.

\section{KESIMPULAN DAN SARAN}

Kegiatan pengabdian berhasil dilaksanakan dengan baik, dimana peserta antusias mengikuti kegiatan dan memberikan respon positif. Kegiatan ini memberikan pemahaman baru kepada petani tentang pentingnya pencatatan dan pembukuan usahatani. Berdasarkan hasil pre-test dan post-test Petani mengalami peningkatan 
pemaham dan peningkatan keterampilan akan manajemen pencatatan usahatani. Petani juga berkenan menerapkan secara berkelanjutan.

Disarankan agar topik pengabdian berikutnya menyasar pada aspek pengelolaan limbah, terutama pengelolaan limbah kotoran sapi yang telah berdampak pada pencemaran lingkungan. Pengelolaan limbah kotoran sapi bisa diarahkan menjadi pupuk kompos atau pupuk organik.

\section{Ucapan Terima Kasih}

Penulis mengucapkan terima kasih kepada Universitas Mataram yang telah memberi dukungan finansial melalui program pengabdian pada masyarakat dengan sumber pendanaan PNBP Universitas Mataram tahun 2021.

\section{Daftar Pustaka}

Bagio \&Athaillah, T. 2020. Pembukuan Usaha Tani Padi di Desa Leuhan Kecamatan Johan Pahlawan Kabupaten Aceh Barat. Jurnal Abdimas Bina Bangsa, 1(1), 80-86.

BPS. 2014. Hasil Pendataan Potensi Desa/ Kelurahan. BPS Lombok Timur.

Huda, S., \& Wikanta, W. 2016. Pemanfaatan Limbah Kotoran Sapi Menjadi Pupuk Organik Sebagai Upaya Mendukung Usaha Peternakan Sapi Potong di Kelompok Tani Ternak Mandiri Jaya Desa Moropelang Kecamatan Babat Kabupaten Lamongan. AKSIOLOGIYA: Jurnal Pengabdian Kepada Masyarakat, 1(1), 26-35.

Leatemia, E. D., \& Sari, R. M. 2012. Pelatihan Pembukuan Usaha tani di Desa Hutumori, Kecamatan Leitimut, Kota Ambon. Jurnal Bakti, 1(1), 17-24.

Mariyono, J. dan Rachmansyah, Y. 2010. Dampak Sekolah Lapangan Pengendalian Hama Terpadu Pada Produksi Kedelai Di Jawa Timur: Analisis Ekonomi. Dinamika Sosial Ekonomi, 6 (2): 129-144.

Mubyarto. 1989. Pengantar EKonomi Pertanian Edisi III. LP3ES. Jakarta.

Nashihuddin, W., \& Aulianto, D. R. 2015. Strategi peningkatan kompetensi dan profesionalisme pustakawan di Perpustakaan Khusus. Jurnal Perpustakaan Pertanian, 24(2), 51-58.

Nugraha, S. P. 2013. Pemanfaatan Kotoran Sapi Menjadi Pupuk Organik. Asian Journal of Innovation and Entrepreneurship, 2(03), 193-197.

Nuryanti, S., \& Swastika, D. K. S. 2011. Peran kelompok tani dalam penerapan teknologi pertanian. In Forum penelitian agro ekonomi (Vol. 29, No. 2, pp. 115-128).

Pujiyono, A., \& Nugraha, H. S. 2016. Strategi Pembentukan Koperasi Pertanian Syariah di Jawa Tengah: Pendekatan Analytical Network Process (Anp). In Seminar Nasional Multi Disiplin Ilmu Unisbank 2016. Stikubank University.

Putri, M. G., Sirma, I. N., \& Bernadina, L. 2020. Manajemen Usahatani Terung Ungu Di Kelurahan Tuatuka Kecamatan Kupang Timur Kabupaten Kupang. Jurnal EXCELLENTIA, 9(01), 50-57.

Ratnasari, D. 2017. Analisis Hubungan Manajemen Usaha tani Padi Sawah Dengan Tingkat Keberhasilan Gapoktan Serumpun (Studi Kasus Gapoktan Serumpun Kota Gorontalo). AGRINESIA. Vol 2 no.1, November 2017.

Septiadi, D., Rosmilawati, R., Usman, A., Tanaya, I. G. L. P., \& Hidayati, A. 2021. Peningkatan Kapasitas Petani Melalui Pelatihan Pembukuan Usahatani di Desa Otak Rarangan Kecamatan Wanasaba Kabupaten Lombok Timur. Jurnal Pengabdian Magister Pendidikan IPA, 4(3).

Tohir, K. 1983. Seuntai Pengetahuan Tentang Usaha Tani Indonesia. Bina Aksara. Jakarta. 